\title{
Rekonstruksi Parate Eksekusi Hak Tanggungan Atas Tanah Yang Berbasis Nilai Keadilan
}

\author{
Zaenal Arifin \\ Notaris dan PPAT Kabupaten Blitar \\ Email: rezae_dm@ymail.com
}

\begin{abstract}
Charging for the guarantee for creditors through the agency of mortgage right, which is based on the provisions of Law No. 4 of 1996 on Mortgage Right, has advantages where the first holder of mortgage right has the right to sell the object of mortgage right on its own power or commonly known as parate execution. However in practice, parate execution can not be carried out in line with expectations and the ideals of the establishment of these legislation. As a result, the creditors does not get easy, legal certainty, and fairness to perform parate execution of security object. This is because parate execution meant in Law No. 4 of 1996 on Mortgage Right, construed as a substitute for hypotik grosse deed, not based on the promise to sell on its own power or "beding van eigenmactig verkoop". Above this, required reconstruction parate execution of mortgage right, so that later can ensure easy, legal certainty, and especially gives fairness to creditors.
\end{abstract}

Keywords : Reconstruction, Parate Execution, Mortgage Right, and Fairness.

\begin{abstract}
Pembebanan atas jaminan bagi kreditur melalui lembaga hak tanggungan yang didasarkan pada ketentuan Undang-Undang Nomor 4 Tahun 1996 Tentang Hak Tanggungan memiliki kelebihan dimana pemegang Hak Tanggungan pertama mempunyai hak untuk menjual obyek Hak Tanggungan atas kekuasaan sendiri, atau lazim dikenal dengan parate eksekusi. Namun demikian, dalam prakteknya parate eksekusi tidak dapat dilaksanakan sesuai dengan harapan dan dengan cita-cita pembentukan undang-undang dimaksud. Akibatnya, kreditur tidak mendapatkan kemudahan, kepastian hukum dan keadilan untuk melakukan parate eksekusi terhadap objek jaminan. Hal ini disebabkan karena, parate eksekusi yang dimaksudkan dalam Undang-Undang Nomor 4 Tahun 1996 Tentang Hak Tanggungan ditafsirkan sebagaimana sebagai pengganti grosse akta hypotik, bukan berdasarkan janji untuk menjual atas kekuasaan sendiri atau "beding van eigenmactig verkoop". Atas hal tersebut diperlukan rekonstruksi parate eksekusi hak tanggungan, sehingga nantinya dapat menjamin kemudahan, kepastian hukum dan utamanya memberi keadilan bagi kreditur.
\end{abstract}

Kata kunci: Rekonstruksi, Parate Eksekusi, Hak Tanggungan, Keadilan

\section{A. Pendahuluan}

Resiko kredit dalam konteks lembaga keuangan merupakan sebuah kejadian umum, namun memiliki dampak negatif yang apabila tidak dapat diatasi akan berpengaruh pada tingkat kesehatan lembaga keuangan tersebut. Sekalipun demikian, resiko ini dapat dikelola dan dikendalikan, dengan cara melakukan tindakan antisipasi dalam hal pemberian kredit. ${ }^{1}$ Oleh karena itu, dalam pemberian kreditnya bank harus memperhatikan prinsip-prinsip pemberian kredit yang benar, ${ }^{2}$ dimana salah satunya adalah melalui penilaian agunan (coleteral) berupa jaminan

1 Adiwarman A. Karim, 2006, Bank Islam: Analisis Fiqih dan Keuangan, Raja Grafindo Persada, Jakarta, hlm. 255.

2 Kasmir, 2007, Manajemen Perbankan, Raja Grafindo Persada, Jakarta, hlm. 91. 
yang dapat digunakan sebagai perlindungan bagi kreditor (lembaga keuangan) apabila terjadi wanprestasi atau cidera janji.

Penggunaan lembaga Hak Tanggungan oleh lembaga keuangan sebagai jaminan atas kredit dari debitur untuk pelunasan hutang dirasa lebih memberikan rasa aman dalam hal pemberian kredit, bila dibandingkan dengan ketentuan mengenai adanya jaminan dalam KUHPerdata pada Pasal 1131. Kelemahan dalam hak jaminan yang terdapat pada ketentuan Pasal 1131 KUHPerdata ini sangat berbeda dengan konsepsi pembebanan jaminan dalam Undang Undang Hak Tanggungan, dimana pembebanan jaminan pada lembaga hak tanggungan diikat secara khusus dan bersifat ekslusif, karena hanya berlaku untuk satu kreditur saja. Hal ini berakibat hukum pada situasi dimana jika debitor cidera janji, kreditor pemegang Hak Tanggungan berhak menjual objek yang dijadikan jaminan melalui pelelangan umum menurut ketentuan peraturan perundang-undangan yang bersangkutan, dengan hak mendahulu dari pada kreditor-kreditor yang lain.

Berdasarkan ketentuan Pasal 6 UndangUndang Nomor 4 Tahun 1996 Tentang Hak Tanggungan Atas Tanah beserta benda-benda yang berkaitan dengan tanah (selanjutnya disebut UUHT), pengambilalihan agunan dapat dilakukan oleh pemegang hak tanggungan tanpa perlu meminta persetujuan terlebih dahulu kepada pemberi Hak Tanggungan, dan tidak perlu juga meminta penetapan pengadilan setempat apabila akan melakukan eksekusi atas Hak Tanggungan yang menjadi jaminan utang debitur dalam hal debitur cidera janji. ${ }^{3}$ Pemegang Hak Tanggungan dapat meminta kepada Kepala Kantor Lelang untuk melakukan pelelangan atas objek Hak Tanggungan yang bersangkutan, ${ }^{4}$ sehingga ini merupakan langkah baru dimana sebelumnya eksekusi atas grosse akta hipotik hanya dapat dilakukan melalui eksekusi di Pengadilan Negeri. ${ }^{5}$ Eksekusi Hak Tanggungan. Konsep ini dikenal dalam Kitab Undang-undang Hukum Perdata (selanjutnya disebut KUHPerdata) dikenal sebagai

\footnotetext{
3 Remy Sjahdeini, 1999, Hak Tanggungan, Asas-asas, Ketentuan-ketentuan Pokok dan Masalah Yang Dihadapi Oleh Perbankan, Alumni, Bandung, hlm. 46.

4 Ibid.

5 Ibid.
}

Parate Eksekusi sebagaimana dimaksud dalam Pasal 1178 ayat KUHPerdata.

Berdasarkan ketentuan tersebut, pengambilalihan agunan berupa jaminan dapat dilakukan oleh pemegang hak tanggungan (kreditur) tanpa perlu meminta persetujuan terlebih dahulu kepada pemberi Hak Tanggungan, apabila akan melakukan eksekusi atas Hak Tanggungan yang menjadi jaminan utang debitur dalam hal debitur cidera janji, konsep ini dikenal sebagai parate eksekusi yang artinya sehingga orang menyebutnya sebagai eksekusi yang selalu siap di tangan atau parate eksekusi. ${ }^{6}$

Pada praktek pelaksanaannya, pelaksanaan parate eksekusi atas hak tanggungan menjadi tidak jelas, bahkan cenderung melenceng jauh dari asas dan doktrin parate eksekusi. Hal ini salah satunya dapat dilihat pada Pasal 14 Ayat (2) dan (3) UUHT, dimana eksekusi dapat dilakukan terhadap sertifikat hak tanggungan yang di dalamnya memuat irah-irah dengan kata-kata: DEMI KEADILAN BERDSARKAN KETUHANAN YANG MAHA ESA. Dengan demikian, frasa dimaksud (irah-irah) menunjukan bahwa eksekusi atas objek jaminan atas tanah yang diikat dengan hak tanggungan dipahami sebagaimana eksekusi sebagaimana grosse acte Hypotheek.

Lain dari itu, pada penjelasan umum Angka 9 dari Undang-undang Hak Tanggungan disebutkan bahwa konsep Parate Eksekusi Hak Tanggungan yang dimaksud dalam Pasal 14 Ayat (3) undangundang tersebut tetap mengacu kepada Pasal 224 Herziene Indonesisch Reglement (selanjutnya disingkat HIR). Ketentuan dalam pasal $224 \mathrm{HIR}$ menyebutkan bahwa:

"Surat asli dari pada surat hipotek dan surat hutang yang diperkuat di hadapan notaris di Indonesia dan yang kepalanya memakai perkataan "Atas nama Undangundang" berkekuatan sama dengan putusan hakim, jika surat yang demikian itu tidak ditepati dengan jalan damai, maka perihal menjalankannya dilangsungkan dengan perintah dan pimpinan ketua pengadilan negeri yang dalam daerah hukumnya orang

6 J Satrio, 1997, Hukum Jaminan Hak Jaminan Kebendaan Hak Tanggungan, Buku I, Citra Aditya Bakti, Bandung, hlm. 224. 
yang berhutang itu diam atau tinggal atau memilih tempat tinggalnya dengan cara yang dinyatakan pada pasal-pasal di atas dalam bagian ini, akan tetapi dengan pengertian, bahwa paksaan badan itu hanya dapat dilakukan, jika sudah diizinkan dengan keputusan hakim. Jika hal menjalankan keputusan itu harus dijalankan sama sekali atau sebahagian di luar daerah hukum pengadilan negeri, yang ketuanya memerintahkan menjalankan itu, maka peraturan-peraturan pada pasal 195 ayat kedua dan yang berikutnya dituruti."

Kondisi ini menyebabkan adanya multi penafsiran yang tidak bertolak belakang antara Pasal 6 jo. Pasal 20 Ayat (1) Huruf (a) UndangUndang Hak Tanggungan, Pasal 14 ayat (3), dan Angka 9 Penjelasan Umum UndangUndang Hak Tanggungan. Kondisi ini akhirnya membuat asas kemudahan dan kepastian hukum parate eksekusi hak tanggungan menjadi tidak tercapai, sebab pada akhirnya kreditur dalam hal ini pemegang hak tanggungan tidak dapat menjalankan eksekusi hak tanggungan dengan mudah sesuai dengan cita-cita pembentukan Undang-Undang Hak Tanggungan sebagaimana yang tercantum dalam Penjelasan Umum Undangundang Hak Tanggungan.

\section{B. Pembahasan}

\section{Pelaksanaan Parate Eksekusi Hak Tanggungan atas tanah dan kelemahan-kelemahannya saat ini.}

Terdapat beberapa kelebihan-kelebihan pengikatan jaminan melalui lembaga hak tanggungan, dimana menurut penjelasan Undang-Undang Nomor 4 Tahun 1996 alenia ke-3 tentang Hak Tanggungan diantaranya adalah ciri mudah dan pasti pelaksanaan eksekusinya. ${ }^{7}$ Kemudahan dan kepastian

7 Penjelasan Undang-Undang Nomor 4 Tahun 1996 alenia ke- 3 tentang Hak Tanggungan menjelaskan, bahwa kelebihan dari lembaga hak tanggungan adalah:

1. Memberikan kedudukan yang diutamakan atau mendahului kepada pemegangnya.

2. Selalu mengikuti obyek yang dijaminkan dalam tangan siapapunobyek itu berada.

3. Memenuhi asas spesialitas dan publisitas sehingga dapat mengikat pihak ketiga dan memberikan kepastian hukum kepada pihak-pihakyang berkepentingan. dalam hal eksekusi atas objek jaminan hak tanggungan diantaranya terdapat pada ketentuan Pasal 6 jo Pasal 20 ayat (1) UndangUndang Nomor 4 Tahun 1996 tentang Hak Tanggungan dimana kreditur diberikan hak untuk mengeksekusi sendiri/langsung objek jaminan atas kekuasaan sendiri yang dikenal sebagai eksekusi langsung, parate executie, eksekusi riil dengan titel eksekutorial, ${ }^{8}$ atau menurut P.A. Stein menyebutnya sebagai "eksekusi yang disederhanakan". ${ }^{9}$

A. Pitlo mengatakan: "De pandhouder verkoopt deze zaak alsware het zijn eigen zaak", atau bila diterjemahkan adalah "Pemegang gadai menjual benda tersebut seakan-akan benda itu miliknya sendiri“. Hal ini dikarenakan oleh pelaksanaan parate eksekusi yang tidak melibatkan debitur atau pemberi-gadai ${ }^{10}$ dan tidak melibatkan Pengadilan dalam pelaksanaan penjualannya atau "zonder omslag". ${ }^{11}$ Senada dengan pelaksanaan eksekusi dan penjualan tanpa melibatkan pengadilan ini, Maria Elisabeth Elijana mengatakan mengenai apa yang dimaksud dengan Parate Eksekusi, dimana: "Eksekusi secara serta merta yang dapat dilakukan tanpa perantara/bantuan Pengadilan". ${ }^{12}$

4. Mudah dan pasti pelaksanaan eksekusinya.

8 Sudikno Mertokusumo berpendapat, Titel Eksekutorial adalah kekuatan untuk dilaksanakan secara paksa dengan bantuan dan oleh alat-alat negara. Sudikno Mertokusumo, 1996, Hukum Acara Perdata Indonesia, Liberty, Yogyakarta, hlm. 211.

9 J. Satrio, 2006, Eksekusi Benda Jaminan Gadai. Prosiding Seminar Sehari Perbankan. Aspek Hukum Corporate Financing Oleh Perbankan di Indonesia: Aturan Penegakan dan Penyelesaian Sengketa Hukum Dalam Hubungan Kreditor dan Debitor, Jurnal Hukum dan Pembangunan FH UI, Jakarta, hIm. 82.

10 Ibid., hlm. 6.

11 A. Pitlo mengatakan bahwa parate eksekusi merupakan eksekusi atas oyek gadai yang dapat dilaksanakan tanpa liku-liku, karena seakan-akan objek tersebut adalah miliknya sendiri. J. Satrio, 1993, Parate Eksekusi Sebagai Sarana Menghadapi Kredit Macet, Citra Aditya Bakti, Bandung, hlm. 113.

12 Maria Elisabeth Elijana, 2006, Eksekusi Barang Jaminan Sebagai Salah Satu Cara Pengembalian Hutang Debitur, Prosiding Seminar Sehari Perbankan, Aspek Hukum Corporate Financing OlehPerbankan di Indonesia: Aturan Penegakan dan Penyelesaian Sengketa Hukum Dalam Hubungan Kreditor dan Debitor, Jurnal Hukum dan Pembangunan FH UI, Jakarta, hIm. 56. 
Namun demikian, faktanya pelaksanaan parate eksekusi sebagaimana yang tersurat pada Pasal 6 UUHT sangat sulit untuk dilaksanakan oleh kreditur. Kesulitan dalam hal pelaksanaan parate eksekusi ini disebabkan adanya kelemahan berupa inkonsistensi dan kerancuan dalam memahami doktrin parate eksekusi, sehingga menyebabkan banyaknya pertentangan baik dalam materi UUHT itu sendiri, maupun aturan-aturan yang lain.

a. Kelemahan Subjektif

a. Inkonsistensi muatan materi dalam UUHT

Konstruksi hukum mengenai parate eksekusi dalam UndangUndang Hak Tanggungan ini secara jelas sudah diatur dalam Pasal 6 dimana secara subtansi pelaksanaan penjualan obyek Hak Tanggungan hanya melaui pelelangan umum, tanpa harus meminta fiat Ketua Pengadilan Negeri. Namun bilamana ketentuan Pasal 6 dihubungkan dengan ketentuan pada Pasal 11 Ayat (2) huruf (e) Undang-Undang Hak Tanggungan, menjadi tidak relevan dan tidak sinkron. Sebab, hak bagi pemegang Hak Tanggungan pertama untuk menjual obyek Hak Tanggungan atas kekuasaan sendiri apabila debitor cidera janji matang, dengan syarat diperjanjikan terlebih dahulu oleh para pihak. Bila dikaji, ketentuan pada Pasal 6 kewenangan parate eksekusi adalah berdasarkan pada perintah Undang-Undang ( $e x$ lege), sementara pada Pasal 11 Ayat (2) huruf (e) didasarkan pada perjanjian.

Inkonsistensi lain juga dapat kita lihat dalam hubungan antara ketentuan Pasal 6 dengan Penjelasan Angka 9 dan Pasal 14 Ayat (2) dan (3) Undang-Undang Hak Tanggungan. Penjelasan Umum Angka 9 mengatur agar parate eksekusi pelaksanaannya didasarkan kepada Pasal 224 HIR/258 RBg yang sebenarnya ditujukan kepada grosse akta hipotik dan grosse akta pengakuan hutang (berdasarkan irah-irah). Apa yang disebutkan dalam Penjelasan angka 9 tersebut tentu saja bertentangan dengan ratio legis dimuatnya ketentuan Pasal 6 tersebut.

Penafsiran berdasarkan undangundang mengenai prosedur parate eksekusi menurut penjelasan angka 9 adalah sama dengan prosedur eksekusi sertifikat Hak Tanggungan, yaitu menggunakan prosedur sesuai dengan Hukum Acara Perdata dimana jika debitor benar-benar cidera janji (wanprestasi) parate eksekusi harus melalui izin dan atas perintah Ketua Pengadilan Negeri untuk dapat melaksanakan janji menjual atas kekuasaan sendiri.

b. Putusan Mahkamah Agung Nomor $3021 / \mathrm{K} / \mathrm{Pdt} / 1984$ tertanggal 30 Januari 1986

Parate eksekusi yang langsung dilakukan ke Kantor Lelang tanpa melalui fiat Ketua Pengadilan Negeri merupakan perbuatan melawan hukum. Dasar dari ketentuan ini berdasarkan pada Putusan Mahkamah Agung Nomor $3210 \mathrm{~K} /$ Pdt/1984 tanggal 30 Januari 1986 dimana dalam dasar pertimbangan sebagai berikut: ${ }^{13}$

a) Bahwa berdasarkan Pasal 224 HIR pelaksanaan pelelangan sebagai akibat adanya grose acta hipotik dengan memakai kepala: "Demi Keadilan Berdasarkan Ketuhanan Yang Maha Esa", yang mempunyai kekuatan hukum sama dengan suatu putusan Pengadilan, seharusnya dilaksanakan atas perintah dan pimpinan Ketua Pengadilan, bilamana tidak

13 Herowati Poesoko, 2007, Parate Eksekusi Objek Hak Tanggungan, Laksbang Pressindo, Yogyakarta, hlm. 319. Lihat juga HP Panggabean, 1992, Himpunan Putusan Mahkamah Agung RI Mengenai Perjanjian Kredit Perbankan (Berikut Tanggapan), Jilid I, Citra Adytia Bakti, Bandung, hlm. 233. 
terdapat perdamaian dalam pelaksanaannya.

b) Bahwa ternyata di dalam perkara ini, pelaksanan pelelangan tidak atas perintah Ketua Pengadilan Negeri Bandung, tetapi diaksanakan sendiri oleh Kepala Kantor Lelang Negara Bandung atas perintah Bank Kreditor, oleh karenanya maka lelang umum tersebut adalah bertentangan dengan Pasal 224 HIR, sehingga pelelangan tersebut adalah tidak sah.

c) Bahwa dengan demikian maka para Tergugat Asal (Bank Kreditor - Kantor Lelang Negara dan pembeli lelang) telah melakukan perbuatan melawan hukum

c. Surat Edaran Mahkamah Agung (SEMA) Nomor 7 Tahun 2012

Pelaksanaan parate eksekusi tersebut, dalam praktek pelaksanaannya juga dimandulkan oleh adanya Surat Edaran Mahkamah Agung (SEMA) Nomor 7 Tahun 2012 angka XIII dari Sub KamarPerdata Umum, dinyatakankan bahwa:

"Pelelangan Hak Tanggungan yang dilakukan oleh kreditor sendiri melalui Kantor lelang, apabila terlelang tidak mau mengosongkan objek yang dilelang, tidak dapat dilakukan pengosongan berdasarkan Pasal 200 ayat (11) HIR melainkan harus diajukan gugatan. Karena pelelangan tersebut diatas bukan lelang eksekusi melainkan lelang sukarela".

b. Kelemahan Objektif

1) Pelaksanaan Parate Eksekusi

Sebagaimana disebutkan dalam Pasal 6 UUHT, apabila debitor cidera janji, pemegang Hak Tanggungan pertama mempunyai hak untuk menjual obyek Hak Tanggungan atas kekuasaan sendiri melalui pelelangan umum serta mengambil pelunasan piutangnya dari hasil penjualan tersebut. Namun demikian, seringkali kreditur tidak melakukan upaya penagihan secara serius dan atau penyelesaian secara kekeluargaan pada saat diketahui debitur telah menunggak atau tidak melakukan pembayaran pada saat jatuh tempo. Namun yang terjadi justru seringkali kreditur melakukan pembiaran berlarut, sehingga debitur terlena sampai menunggak pembayaran dalam jumlah besar, dan pada saat itulah kreditur melakukan tindakan eksekusi secara kasar tanpa ada pilihan lain.

Selain itu, seringkali kreditur menggunakan jasa pihak ke-3 (debt collector) untuk melakukan upaya penagihan, maupun eksekusi terhadap debitur. Seringkali debt collector melakukan tindakantindakan yang dianggap melanggar hukum dengan melakukan intimidasi, pressure, maupun hal-hal lain yang justru membuat debitur merasa dirugikan. Alhasil, hal tersebut justru membuat masalah baru, yang jauh dari konteks penyelesaian masalah. ${ }^{14}$

2) Perlawanan debitur

Seringkali parate eksekusi justru melahirkan polemik baru, dimana pelunasan kredit dari debitur kepada kreditur tidak dapat dilakukan secara cepat, mudah, dan efisien. Hal ini tidak lepas dari kenyataan bahwa debitur seringkali melakukan upaya perlawanan, baik itu pada saat pelaksanaan lelang, maupun setelah ditetapkannya pemenang lelang oleh lembaga lelang. Diantaranya adalah kasus lelang Bank NISP melawan

14 Lihat Peraturan Bank Indonesia (PBI) No. 11/11/ $\mathrm{PBI} / 2009$ tentang Penyelenggaraan Kegiatan Alat Pembayaran dengan Menggunakan Kartu ("PBI") jo SE BI No. 11/10/DASP Perihal Penyelenggaraan Kegiatan Alat Pembayaran dengan Menggunakan Kartu tanggal 13 April 2009 (“SEBI"). 
nasabahnya, Koo Ay Tjen. Koo Ay Tjen mengajukan perlawanan terhadap rencana eksekusi oleh Bank NISP. ${ }^{15}$ Perlawanan ini secara nyata akan mengakibatkan kerugian bagi kreditur sebab, dari sisi biaya dan waktu akan terkuras, sedangkan disisi lain kerugian juga akan diderita debitur, sebab nilai pelunasan kredit akan bertambah banyak dikarenakan bertambahnya waktu, dan biaya lain.

2. Rekonstruksi Parate Eksekusi Hak Tanggungan atas tanah yang berbasis nilai keadilan.

a. Mereposisi tujuan utama pelaksanaan parate eksekusi.

Dasar ketentuan parate eksekusi terdapat pada Pasal 6 UUHT, dimana disebutkan bahwa:

"Apabila debitor cidera janji, pemegang Hak Tanggungan pertama mempunyai hak untuk menjual obyek Hak Tanggungan atas kekuasaan sendiri melalui pelelangan umum serta mengambil pelunasan piutangnya dari hasil penjualan tersebut."

Membongkar konsep keadilan dalam parate eksekusi tidak dapat dilihat secara parsial, sepotong-sepotong, dan terpisah antara tujuan filosofis dan pelaksanaannya, namun harus secara komprehensip di dalami secara menyeluruh. Artinya, nilai keadilan yang terkandung dalam doktrin parate eksekusi harus berangkat dari konsep dasar adanya hak dan kewajiban yang lahir dan harus dilaksanakan oleh kreditur dan debitur dalam melaksanakan perjanjian kredit. Secara filosofis keinginan akan adanya keadilan dalam parate eksekusi lahir untuk melindungi kepentingan kreditur disatu sisi, dan disisi lain untuk menjaga debitur untuk melakukan kewajiban pembayaran atas

15 http://www.hukumonline.com/berita/baca/ It4c594a3da06e6/perlawanan-eksekusi-lelangbank-nisp-kandas., diakses pada hari Selasa 19 April 2016, Pukul 9.30 fasilitas pembayaran kredit yang telah diterimanya.

Senada dengan hal tersebut, John Rawls memberikan penekanan keadilan dapat dicapai manakala pendistribusian hak dan kewajiban dalam masyarakat terjadi secara berimbang. Sebab dengan perimbangan hak dan kewajiban, maka setiap orang berpeluang memperoleh manfaat darinya dan secara nyata, serta menanggung beban yang sama. ${ }^{16} \mathrm{Hal}$ ini diartikan bahwa keadilan akan tercapai bilamana antara kreditur dan debitur sama-sama melakukan kewajiban sesuai dengan kesepakatan. Oleh karenanya maka bilamana kreditur telah melakukan kewajiban, dan debitur telah melakukan hak menerima fasilitas kredit, maka seharusnya debitur harus melakukan kewajiban pembayaran terhadap kreditur sebagai gantinya.

Distorsi makna parate eksekusi dengan mencampurbaurkannya dengan makna eksekusi grosse akta dengan dasar Pasal 224 HIR yang harus melalui fiat penetapan Ketua Pengadilan ${ }^{17}$ justru menjauhkan dari sisi keadilan. Tentu keadilan bagi kreditur yang tidak hanya harus menanggung kerugian karena tidak dilaksanakannya kewajiban pembayaran kredit oleh debitur, namun disaat bersamaan kreditur (lembaga keuangan/bank) harus membuat cadangan PPA sebesar 100\% (seratus persen) dari total nilai kredit tersebut dikurangi dengan nilai agunan. ${ }^{18} \mathrm{Di}$ sisi lain, permasalahan tersebut juga semakin memperberat konsekuensi logis dari debitur, sebab dengan semakin lama waktu penyelesaian, maka semakin berat beban tanggungan kredit yang

16 John Rawls, 1971, A Theory of Justice, Oxford University Press, London, hlm. 4-5.

17 M. Yahya Harahap, Kedudukan Grosse Akte Dalam Perkembangan Hukum di Indonesia, Media Notariat No: 8-9, tahun III, Oktober 1988, hlm. 113.

18 Peraturan Bank Indonesia No.7/2/PBI/2005 Tentang Penilaian Kualitas Aktiva Bank Umum, sebagaimana yang telah dirubah terakhir kalinya melalui Peraturan Bank Indonesia Nomor 11/2/PBI/2009. 
ditanggung debitur serta membuka kemungkinan terjadinya sengketa di pengadilan.

b. Revitalisasi aspek yuridis melalui singkronisasi aturan perundangundangan, dan pemenuhan aturan pelaksana.

Secara gramatikal, parate eksekusi matang bilamana terjadi cidera janji/ wanprestasi, dan pelaksanaannya dapat dilakukan sendiri, namun tetap harus melalui pelelangan umum. Artinya aspek kesewenang-wenangan yang lahir dari frasa "kekuasaan sendiri" secara jelas langsung dibatasi oleh frasa "pelelangan umum" dengan maksud menghadirkan keadilan untuk debitur untuk mendapatkan harga yang sesuai dengan nilai objek jaminan yang dijual.

Salah satu problem yang menjadi polemik adalah bahwa adanya frasa "cidera janji" yang dianggap kontroversial dan berpolemik. Sebab, cidera janji juga diatur dalam KUHPerdata dan harus dibuktikan melalui gugatan wanprestasi. Sebaliknya, dalam ketentuan Pasal 6 UUHT sendiri, tidak memerlukan pembuktian melalui putusan pengadilan, sebab cukup dibuktikan melalui bukti kelalaian pembayaran saat jatuh tempo, dan atau melalui pemberitahuan dari kreditur terhadap debitur. Hal ini dapat dipahami bahwa ketentuan pelaksanaan parate eksekusi merupakan perintah Undang-undang (ex lege) bukan berdasarkan perjanjian. Sehingga sebagai Undang-Undang khusus, sesuai dengan asas Lex specialis derogat legi generali maka UUHT merupakan aturan hukum yang bersifat khusus (lex specialis) dan mengesampingkan KUHPerdata (lex generalis).

Sebagai pemenuhan aspek yuridis, tentunya sinkronkronisasi aspek yuridis sebagai dasar legalitas parate eksekusi mutlak dilakukan guna memperkecil potensi terjadinya ketidakadilan. Sinkronisasi ini tentunya terkait dengan adanya yurisprudensi berdasarkan
Putusan Mahkamah Agung Nomor 3021/K/Pdt/1984 tertanggal 30 Januari 1986 yang bertolak belakang dengan ketentuan UUHT utamanya pada Pasal 6. Berdasarkan asas "Lex posteriori derogat legi priori”, artinya hukum yang baru mengesampingkan hukum yang lama, maka secara langsung yurisprudensi dimaksud tidak dapat dijadikan dasar hukum pembatalan pelaksanaan parate eksekusi.

Lebih lanjut, sesuai dengan tata urutan perudang-undangan UU Nomor 12 Tahun 2011, maka sebuah Surat Edaran (Mahkamah Agung) dalam hal ini Surat Edaran Mahkamah Agung (SEMA) Nomor 7 Tahun 2012 tidak termasuk tata urutan perundangan, sehingga tidak dapat dijadikan alasan atau dasar hukum untuk menolak eksekusi hak tanggungan berdasarkan pada parate eksekusi dalam UUHT.

Hal lain adalah perlunya diterbitkan peraturan pelaksanaan yang mengatur hal teknis parate eksekusi, sebab salah satu aspek penghambatnya adalah ketiadaan aturan pelaksanaan parate eksekusi itu sendiri. Tentu aturan pelaksana parate eksekusi ini tidak semta-mata pelengkap, namun lebih jauh aturan pelaksana parate eksekusi ini berfungsi sebagai rule of procedure yang dipahami bersama oleh kreditur dan debitur. Pemahaman bersama soal rule of procedure ini akan melahirkan sikap hati-hati, saling menghormati dan saling menguntungkan pihak kreditur maupun debitur, sehingga bila terjadi parate eksekusi maka pihak debitur akan menghormati dan menghargai karena kepentingannya juga akan diakomodir.

Oleh karenanya, seharusnya parate eksekusi tetap berada dalam frame pelaksanaan eksekusi hak kreditur atas obyek jaminan, dimana pelaksanaanya tanpa (di luar) melalui ketentuan hukum acara, tanpa penyitaan, tanpa melibatkan juru sita, tanpa izin pengadilan. Hal 
ini merupakan wujud dari kedudukan yang diutamakan oleh lembaga Hak Tanggungan yang ada pada UUHT, namun tetap dalam koridor adil bagi semua pihak, baik kreditur maupun debitur.

\section{Penutup.}

\section{Kesimpulan}

Pelaksanaan Parate Eksekusi Hak Tanggungan atas tanah secara praktek pelaksanaannya sangat sulit dilakukan karena terjadi distorsi makna dimana parate eksekusi dipersamakan dengan eksekusi grosse akta yakni fiat Pengadilan. Kelemahankelemahan pelaksanaan parate eksekusi diantaranya adalah karena problem subjektif yang berupa inkonsistensi antara pasal 6 dengan pasal 11 ayat (2) dan Penjelasan angka (9) UUHT, Putusan Mahkamah Agung Nomor 3021/K/Pdt/1984, serta Surat Edaran Mahkamah Agung (SEMA) Nomor 7 Tahun 2012. Sementara itu, problem objektif adalah masalah pelaksanaan parate eksekusi itu sendiri, serta adanya perlawanan hukum atas parate eksekusi dari debitur.

\section{Saran}

Rekonstruksi Parate Eksekusi Hak Tanggungan atas tanah yang berbasis nilai keadilan dilakukan dengan cara mereposisi tujuan utama pelaksanaan parate eksekusi yakni menghadirkan keadilan melalui penempatan dan pemenuhan hak dan kewajiban para pihak sebagai tujuan utama, serta revitalisasi aspek yuridis melalui singkronisasi aturan perundang-undangan, dan pemenuhan aturan pelaksana.

\section{DAFTAR PUSTAKA}

\section{Buku-Buku:}

Adiwarman A. Karim, 2006, Bank Islam: Analisis Fiqih dan Keuangan, Raja Grafindo Persada, Jakarta.

Herowati Poesoko, 2007, Parate Eksekusi Objek Hak Tanggungan, Laksbang Pressindo, Yogyakarta.

HP Panggabean, 1992, Himpunan Putusan Mahkamah Agung RI Mengenai Perjanjian Kredit Perbankan (Berikut Tanggapan), Jilid I, Citra Adytia Bakti, Bandung.

J Satrio, 1997, Hukum Jaminan Hak Jaminan Kebendaan Hak Tanggungan, Buku I, Citra Aditya Bakti, Bandung.

1993, Parate Eksekusi Sebagai Sarana Menghadapi Kredit Macet, Citra Aditya Bakti, Bandung

John Rawls, 1971, A Theory of Justice, Oxford University Press, London.

Kasmir, 2007, Manajemen Perbankan, Raja Grafindo Persada, Jakarta.

Remy Sjahdeini, 1999, Hak Tanggungan, Asas-asas, Ketentuan-ketentuan Pokok dan Masalah Yang Dihadapi Oleh Perbankan, Alumni, Bandung.

Sudikno Mertokusumo, 1996, Hukum Acara Perdata Indonesia, Liberty, Yogyakarta.

\section{Jurnal-Jurnal}

J. Satrio, 2006, Eksekusi Benda Jaminan Gadai. Prosiding Seminar Sehari Perbankan. Aspek Hukum Corporate Financing Oleh Perbankan di Indonesia: Aturan Penegakandan Penyelesaian Sengketa Hukum Dalam Hubungan Kreditor dan Debitor, Jurnal Hukum dan Pembangunan FHUI, Jakarta.

Maria Elisabeth Elijana, 2006, Eksekusi Barang Jaminan Sebagai Salah Satu Cara Pengembalian Hutang Debitur, Prosiding Seminar Sehari Perbankan, Aspek Hukum Corporate Financing OlehPerbankan di Indonesia: Aturan Penegakan dan Penyelesaian Sengketa Hukum Dalam Hubungan Kreditor dan Debitor, Jurnal Hukum dan Pembangunan FH UI, Jakarta. 
M. Yahya Harahap, Oktober 1988, Kedudukan Grosse Akte Dalam Perkembangan Hukum di Indonesia, Media Notariat No: 8-9, tahun III.

Peraturan Perundang-Undangan, dan Peraturan Lain :

Herziene Indonesisch Reglement

Kitab Undang-Undang Hukum Perdata

Undang-Undang Nomor 4 Tahun 1996 Tentang Hak Tanggungan Atas Tanah Beserta Bendabenda yang Berkaitan Dengan Tanah

Undang-Undang Republik Indonesia Nomor 12 Tahun 2011 Tentang Pembentukan Peraturan Perundang-Undangan

Putusan Mahkamah Agung Nomor 3021/K/Pdt/1984

Surat Edaran Mahkamah Agung (SEMA) Nomor 7 Tahun 2012

Peraturan Bank Indonesia No. 11/11/PBI/2009 tentang Penyelenggaraan Kegiatan Alat Pembayaran dengan Menggunakan Kartu ("PBI") jo SE BI No. 11/10/DASP Perihal Penyelenggaraan Kegiatan Alat Pembayaran dengan Menggunakan Kartu tanggal 13 April 2009 ("SEBI").

Peraturan Bank Indonesia No.7/2/PBI/2005 Tentang Penilaian Kualitas Aktiva Bank Umum, sebagaimana yang telah dirubah terakhir kalinya melalui Peraturan Bank Indonesia Nomor 11/2/PBI/2009.

Website :

http://www.hukumonline.com/berita/baca/lt4c594a3da06e6/perlawanan-eksekusi-lelangbank-nisp-kandas 